\title{
MIESZKAŃCY ROSYJSKIEJ WSI WOBEC WYZWAŃ POSTSOWIECKIEJ RZECZYWISTOŚCI W TWÓRCZOŚCI IRINY MAMAJEWEJ
}

\author{
INHABITANTS OF RUSSIAN RURAL AREAS IN THE CONTEXT \\ OF CHALLENGES OF POST-SOVIET REALITY \\ IN IRINA MAMAYEVA'S WORKS
}

\author{
LILIANA KALITA
}

\begin{abstract}
AвStRAct. The paper analyses Irina Mamayeva's short stories and tales that show the life in Russian rural areas during a dozen or so years following perestroika, and point out its influence on both individual life and that of a village community as a group. The picture of the rural areas in the 1990s and at the beginning of the $21^{\text {st }}$ century is pessimistic, filled with images of dilapidating houses, companies being shut down, lack of transport connections. This material destruction is accompanied by the spiritual degradation of the inhabitants: poverty, unemployment, mutual aggression and the feeling of being abandoned by the previous system.
\end{abstract}

Keywords: contemporary rural prose, social and political changes, system transformation, Russia after perestroika

Liliana Kalita, Uniwersytet Gdański, Gdańsk - Polska, fillk@ug.edu.pl

ORCID ID: 0000-0002-6025-2643

Irina Mamajewa (ur. 15.04.1978) „szybko stała się sławna, szybko wydała książkę, otrzymała nagrodę, zachwyt krytyków i dalej jej los potoczył się według schematu: od publikacji w poważnych czasopismach i wyjazdów zagranicę na seminaria literackie po spotkania na Kremlu z głowami państwa" - w tych kilku słowach Zachar Prilepin charakteryzuje obecność na literackiej scenie Rosji pisarki pochodzącej z Pietrozawodska, stolicy Republiki Karelii. Mamajewa z wykształcenia jest zootechnikiem. Studiowała również w Instytucie Literackim, ale przerwała naukę. Pracowała jako zootechnik, ujeżdżacz koni, dziennikarka. Debiut pisarki to opowieść Wesele Lenki (Ленкина сbадъба) opublikowana w „Drużbie narodów” w 2005 roku. Mamajewa jest autorką m.in. takich utworów jak: Ziemia Gaj (Земля Гай, 2006), Morze ty moje (Море ты мое, 2006), Z debilna twarza (С дебильным лицом, 2007), Butla (Бутыль, 2010). Jej teksty pojawiały się na łamach czasopism „Наш современник”, „Север”, „Урал", ,"Carelia”, w gazetach „Лицей”, ,Литературная Россия", ,„Литера- 
турная газета", w zbiorkach Стихи не приходят по зову.., Волны трав, Новые писатели. Pisarka była wielokrotnie nagradzana. Otrzymała m.in. nagrody: „Открытая Россия” (2004), „Соколофф-приз” (2005), „Эврика” (2006), a także nagrody imienia Walentina Rasputina (2007), Antona Delwiga (2008), czasopisma „Дружба народов" (2010).

Twórczość Mamajewej zaliczana jest do nurtu wiejskiego we współczesnej prozie, jej nazwisko wymienia się obok takich twórców jak Ilia Koczergin, Wasilij Awczenko, Aleksandr Buszkowskij, Borys Jekimow czy Roman Sienсzyn [Микоян 2016]. Jak zauważa Natalia Igrunowa w recenzji Ziemi Gaj „[...] korzenie tej prozy są Rasputinowskie [...]. Spojrzenie jednak współczesne, swoje, opowieść zawiera pewien nerw, który zmusza nie tylko do czytania, ale też do przeżywania wielkich nieszczęść i maleńkich radości bohaterów" [2007]. Wspomniana wyżej opowieść zaliczana jest do najlepszych tekstów pisarki, podejmuje kwestie losu mieszkańców współczesnej wsi, podlegającej nieuniknionym przemianom, będącym skutkiem transformacji ustrojowej i jej praktyk, jak również odpowiedzialności starszych pokoleń za kształt obecnej rzeczywistości, dotyka kwestii tożsamości narodowej obywateli krajów wchodzących w skład Związku Radzieckiego, zawiera też odniesienia do historii porewolucyjnej kraju. Poruszona w Ziemi Gaj problematyka pozwala ujrzeć skomplikowane kwestie społeczno-historyczne, które determinują egzystencję bohaterów i ich postawy wobec świata w wymiarze uniwersalnym.

Autorka Rosomachi (Росомаха, 2009) świat przedstawiony swoich utworów lokuje zwykle na odległej rosyjskiej prowincji, w karelskich wioskach, czy siołach, skąd daleko jest do większych skupisk ludzkich i gdzie rzadko docierają nowoczesne zdobycze cywilizacji. Echem pradawnego stylu życia bywa uciekanie się do korzystania $\mathrm{z}$ magii $\mathrm{w}$ sytuacjach szczególnie trudnych, jak np. konflikt z sąsiadką czy opuszczenie przez mężczyznę. Funkcjonowanie $w$ takich miejscowościach toczy się $\mathrm{z}$ reguły obok lub na przekór dokonującym się na innych obszarach kraju zmianom, pozostawieni samym sobie i borykający się z trudnościami codziennymi ludzie narzekają na swój los i topią smutki oraz poczucie beznadziei w alkoholu. Mamajewa pokazuje swoich bohaterów w kilka lub kilkanaście lat po pierestrojce, diagnozując, jaki wpływ miała ona na sytuacje pojedynczego człowieka - mieszkańca wsi i wiejskiej społeczności jako grupy. Koncentracja autorskiej uwagi na procesach zachodzących na wsi wydaje się nieprzypadkowa. Rosja niemalże do połowy XX wieku była krajem, w którym większość ludności stanowili chłopi żyjący z uprawy ziemi, a kultura wiejska uważana była za kolebkę rosyjskiej cywilizacji, dlatego też analizując obecny stan wsi i jej mieszkańców Mamajewa mówi o kondycji moralno-intelektualnej całego kraju. Wieś odzwierciedla i skupia te zjawiska - w większości negatywne - które obecne są i poza nią. Obraz wsi lat 90. i 2000., z jakim mamy do czynienia w utworach pisarki 
z Pietrozawodska, jest pesymistyczny - wypełniają go opisy rozpadających się domów, zamkniętych cerkwi i szkół, niedziałających zakładów pracy, braku połączeń komunikacyjnych. Destrukcji materialnej towarzyszy rozpad duchowy mieszkańców: ubóstwo, bezrobocie, wzajemna agresja i poczucie pozostawienia na łasce losu przez władze poprzedniego systemu.

Stan rosyjskiej wsi po pierestrojce i dokonujących się w niej przeobrażeń jest przedmiotem analiz socjologicznych i gospodarczych. Zdaniem Aleksandra Mierzłowa, od czasu transformacji ustrojowej z mapy Rosji zniknęło od 20 do 30 tys. miejscowości: „w czasie ostatnich 15-20 lat stale maleje liczba ludności wiejskiej, czy to z powodów naturalnych (śmiertelność przewyższa liczbę urodzeń) czy też z powodów migracji do miast" [Мерзлов 2016]. Głównym powodem opuszczania wsi jest bezrobocie, które - według danych statystycznych - jest dwukrotnie większe na wsi niż w mieście. Według Mierzłowa mieszkańców wsi w większym stopniu dotyka również bezrobocie długotrwałe: „35\% znajduje się w sytuacji bezrobocia długotrwałego (poszukują pracy przez 12 miesięcy lub więcej)" [Мерзлов 2016]. Piotr Eberhardt z kolei zwraca uwagę, iż w wyniku procesów urbanizacyjnych zmieniła się struktura ludności wiejskiej: „Pozostawali na miejscu ludzie starzy o niskich kwalifikacjach i małych aspiracjach. Kołchozowa wieś rosyjska zaczęła ulegać wyludnieniu i pauperyzacji. Tysiące wsi traciło wszystkich swoich mieszkańców" [Eberhardt 2013: 83].

Podobnego losu nie uniknęła wioska o nazwie Ziemia Gaj. Sytuacja demograficzna panująca w niej w pierwszych latach XXI wieku potwierdza tendencję schyłkową:

В Гае проживает 197 человек, из них 75 человек пенсионного возраста, 112 человек трудоспособного возраста и 10 несовершеннолетних. Из 112 трудоспособных работает 12 человек: семеро - путейскими рабочими на Октябрьской железной дороге, один оформлен фермером, один - частным предпринимателем, одна женщина - медсестрой от Койвусельгской амбулатории, двое посменно пасут общественное стадо. Остальные стоят на бирже труда и получают пособие по безработице. В поселок два раза в неделю приезжает автолавка с продуктами, раз в неделю - машина с почтой, два раза в месяц доставляют пенсии [Мамаева 2006].

Czynnikiem, który wpłynął na obniżenie samodzielności wsi i jakości życia jej mieszkańców była również zmiana modelu ekonomicznego: „Na skutek wprowadzenia gospodarki rynkowej - pisze Eberhardt - nastąpił upadek zakładów przemysłowych usytuowanych w północnej i wschodniej części kraju" [Eberhardt 2013: 76]. Ten problem znajduje odzwierciedlenie zarówno w Ziemi Gaj, jak i w opowiadaniu Mamajewej Butla. Akcja ostatniego utworu rozgrywa się w małej wiosce o nazwie Putiejnyj, która w czasach ZSRR była ważnym węzłem przeładunkowym dla wydobywanego z okolicznych lasów drewna. W pamięci Nikołaja Wiktorowicza Abramowa, który jako dziecko 
spędzał wakacje u babci i dziadka, obraz wsi wiąże się z widokiem szyn i trakcji kolejowych: „...Тянутся рельсовые нити, сужается междупутье, оканчиваясь стрелочным переводом. Переводов становится все больше и больше - разбегаются стрелочные улицы: в Лесной, в Заречный, в Заоблачный" [Мамаева 2010]. Kolej dawała zatrudnienie niemalże wszystkim mieszkańcom wioski. Taka sytuacja trwała do pierestrojki, kiedy to „все закончилось резко и неожиданно. Загнулся леспромхоз со всеми лесопунктами - нечего стало возить по путям, незачем стало следить за путейным хозяйством. И все как-то сразу захирело, заросло сначала травой, потом - деревцами" [Мамаева 2010]. Najlepiej ze zmianami gospodarczymi wydaje się radzić sobie sowchoz wioski Kujtieżi, w którym dzieje się akcja Wesela Lenki. Stał się on fermą hodowli zwierząt domowych, zapewniając pracę okolicznej ludności. Część mieszkańców wioski (rodzice Lenki) prowadzi też prywatne gospodarstwa, a jeden z mężczyzn, wyróżniający się spośród miejscowej ludności tym, że nie pije i nigdy nie odmawia pomocy, zdecydował się nawet na założenie własnej firmy, zajmującej się skupem runa leśnego. Wprawdzie nawet i w sowchozie dochodzi do nadużyć, kiedy to dobrej jakości karma podawana jest zwierzętom nie codziennie, ale co drugi dzień, a zaoszczędzone nadwyżki sprzedawane są nielegalnie, jednak jest to jedyny przykład malwersacji, jaki ma miejsce, w odróżnieniu od utworu Ziemia Gaj, którego bohaterowie za zamknięcie fabryki przemysłu drzewnego obwiniają władze sprywatyzowanego zakładu, nieradzące sobie z zarządzaniem $\mathrm{w}$ nowych warunkach ekonomicznych i nastawione na szybkie pomnożenie własnego, a nie społecznego kapitału. Robert Conquest uważa, iż afery gospodarcze, jak chociażby te dotyczące wioski Ziemia Gaj

[...] stanowią dziedzictwo postsowieckie. Kiedy porządek socjalistyczny się zawalił, jedyną grupą z dostępem i doświadczeniem w sprawach ekonomicznych była warstwa państwowej biurokracji, która w iście marksistowskim stylu zadbała o swoje interesy klasowe. Najlepiej ustosunkowani i najbardziej aktywni posłużyli się nowo powstałym wolnym rynkiem do (jak to się często określa) "rozgrabienia” zasobów kraju. Niższe szczeble biurokracji nadal pasożytowały na gospodarce, biorąc łapówki za zezwolenia i tak dalej [Conquest 2002: 262-263].

Obraz urzędników, z pogardą i wyższością traktujących starych i ubogich mieszkańców wioski przynosi nam opowieść Ziemia Gaj. Mamajewa kreśli opis biesiady lokalnej władzy, której przedstawiciele po spotkaniu z mieszkańcami, ale już we własnym gronie i przy alkoholu, omawiają sytuację w okręgu. Ich zachowanie i wyrażany do mieszkańców stosunek pełen jest lekceważenia, pogardy i dystansu. Mieszkańcy Ziemi Gaj nazywani są „bydłem”, uprzedmiotowienie ludzi odbywa się również poprzez zastosowanie wobec nich epitetu „иликторат", który - podany w formie regionalnej 
- jest oznaką szyderstwa wypowiadających. Obserwujemy tutaj też sytuację dobijania targu między szefem okręgowej administracji a zastępcą dyrektora przedsiębiorstwa przemysłu drzewnego, co do kwoty dotyczącej opłaty za opał. Negatywny odbiór osób związanych z władzą uzyskuje Mamajewa pokazując również wewnętrzne animozje pomiędzy poszczególnymi osobami. Mają one tło narodowościowe (sugerowany konflikt pomiędzy Białorusinem Malutinem a Gruzinem Lalaszwili) lub dotyczą kariery zawodowej (zazdrość o ewentualne awanse urzędnicze i związane z tym przenosiny do Moskwy). Zachowanie urzędników, pełne okrucieństwa i naznaczone stereotypowymi wyobrażeniami, znajduje też odzwierciedlenie w dramatycznej scenie odebrania córki samotnemu ojcu. Dziewczynka ma trafić do domu dziecka, gdyż jej ojciec - Cygan Waśka, to, zdaniem urzędników, złodziej, a sam fakt bycia mężczyzną odbiera mu jakoby prawo dobrego wychowania istoty płci żeńskiej. Arogancki stosunek dyrektora domu dziecka do Waśki, brak chęci współpracy i rozważenia innych możliwości udzielenia pomocy rodzinie przywodzi raczej na myśl chęć przejęcia pełnej kontroli nad losem ludzi, dla których wolność i przestrzeń jest niezwykle ważna, niż udzielenia realnej pomocy.

Rysując panoramę bytu mieszkańców współczesnej rosyjskiej wsi Mamajewa nie pozostawia bez uwagi tych, którzy podjęli próbę wykorzystania szansy, jaką dała pierestrojka. W Weselu Lenki takim bohaterem jest, wspomniany już wyżej, Gienka, który „поболтавшись в городе, поработав кемто где-то, женившись и разведясь, вышел на пенсию и вернулся в деревню" [Мамаева 2005]. Bohater odznacza się uporem i pracowitością, dba o firmę, jako jedyny we wsi zainstalował w swoim biurze telefon, jednak nie można powiedzieć, żeby dorobił się wyjątkowego bogactwa - wprawdzie zamienił żiguli na nivę, jednak wciąż jest to auto rodzimej produkcji marki Łada. Innym bohaterem, który wziął los w swoje ręce, jest Fiodor Panasionok z Ziemi Gaj,

[...] не старый еще мужик, он был из тех, кто чувствовал себя хозяином не только своих коров и сараев, но и полей, лесов, рек - всей земли лишь потому, что родился на ней, с детства работал на нее, поливал своим потом, и если уж не оспаривать существование небесного града, куда мы все однажды вернемся, то Федька был уверен, что и там ему давно припасено не самое худшее местечко [Мамаева 2006].

Fiodor wydzierżawił od lokalnego sowchozu traktor i ziemię, jednak wieloletnia praca na roli nie przyniosła mu efektów, jakich się spodziewał. Bohater pracował wciąż więcej i więcej, lata mijały „но как-то все то же и оставалось, не менялось, застыло все давно, закостенело, и вновь купленные коровы оказывались не хуже и не лучше забитых на мясо. Техника вет- 
шала, доски в сараях рассыхались" [Мамаева 2006]. Próżny trud Fiedki nie tylko nie zostaje nagrodzony, ale los okrutnie zakpi z jego zaangażowania i odpowiedzialności. Dobytek bohatera zostaje spalony, gdy nieznani sprawcy podkładają ogień w jego gospodarstwie. Zrozpaczony Fiodor, na pytanie o straty wywołane pożarem, odpowie: „веру у меня украли”, mając na myśli krach swoich wyobrażeń o uczciwej pracy i nadzieję na odrobinę lepszego życia. Opowieść Mamajewej Ziemia Gaj nazwać można kroniką ludzkich rozczarowań. Pisarka pokazuje nam mieszkańców wsi różniących się wiekiem, statusem społecznym, doświadczeniem i podejściem do życia, jednak - poza dotkniętą sklerozą Kuźminiczną - niemal powszechnym uczuciem bohaterów jest złość i smutek, rozgoryczenie i zawiść, budzące wzajemną agresję. Towarzyszy temu poczucie braku winnych takiego stanu rzeczy i przekonanie o niezmienności sytuacji. Starsze pokolenie (Michajłowna) ma pretensje o rozkradaną ojczyznę, na rzecz której pracowali, ofiarując najlepsze swoje lata i siły, pokolenie 40-50-latków (Fiodor), które uwierzyło w hasła pierestrojki, czuje się oszukane wizjami dobrobytu, jaki miał nastąpić, pokolenie 20-latków natomiast (Jegorka) zdaje sobie sprawę, iż podstawą wszystkiego są duże pieniądze, te jednak jakoś omijają mieszkańców wsi, a to powoduje frustrację i brak nadziei na przyszłość. Mamajewa ukazuje ludzi dotkniętych jeśli jeszcze nie depresją, to z pewnością melancholią, opartą na stracie idei, w które mocno się wierzyło i które nie zostały zastąpione innymi wartościami. Filozof Andrzej Leder, oceniając kondycję człowieka we współczesnym świecie, stwierdza, iż „ta cywilizacja jest bezwzględna. Albo ktoś sobie dobrze radzi społecznie, albo idzie na śmietnik" [2015: 15]. Transformacja ustrojowa spowodowana pierestrojką, która wiązała się ze zmianą formy państwa z opiekuńczej na urynkowioną, dotknęła przede wszystkim mieszkańców wsi, pozostawiając ich swojemu losowi, co z kolei powodowało ucieczkę czy to w sferę religii (np. Kuźminiczna w Ziemi Gaj) czy w autoagresję, jaką jest nadużywanie alkoholu, co obserwujemy w każdym z omawianych utworów. Tym samym Mamajewa rysuje nam wieś i jej mieszkańców jako społeczność zdominowaną przez cywilizację melancholii. Żal, smutek, poczucie przegranej, utrata dotychczasowej tożsamości i funkcjonowania w ściśle określonych wzorcach społecznych oraz trudności z wypracowaniem nowych wartości są tu wszechobecne.

Zderzenie tradycyjnej, dla małych i zamkniętych społeczności, mentalności z nowoczesną obyczajowością, która wraz z pierestrojką, zaczyna docierać do wsi pozwala dostrzec, jak silnie zakorzenione są w ludziach pewne schematy myślowe i jak trudno jest otworzyć się na inność. Fabuła Wesela Lenki oparta jest na ideologicznej opozycji miasto - wieś, przy czym obie kategorie waloryzowane są jednoznacznie. To dość schematyczne, przypominające sowiecką epokę, podejście nieco zbyt deklaratywnie, moim zdaniem, wyraża 
stanowisko pisarki, obecne także w innych jej utworach, iż tylko wieś i jej mieszkańcy są nosicielami pierwiastka kolektywnego, będącego podstawą tożsamości Rosjanina. We wspomnianej wyżej opowieści to, co pochodzi z zewnątrz przynosi mieszkańcom wsi ból i chaos. Mieszkanką miasta jest Anka Mitkina, która co roku przyjeżdża na wieś na wakacje, a w fabule utworu jej rola sprowadzona zostaje przede wszystkim do bycia miejscową uwodzicielką i rywalką Lenki o względy Jury. Dyskredytacji Anki służy sposób, w jaki zostaje opisany jej wygląd (karykaturalny, bo przesadnie demonstracyjny), czy reakcje na wypowiedzi o wyższości miasta nad wsią (jej przewaga intelektualna i kulturowa zostaje zakwestionowana, gdy okaże się, że Anka w teatrze była tylko raz i to $\mathrm{z}$ całą klasą). Postać bohaterki zostaje więc w sposób zamierzony strywializowana i w dużej mierze nosi cechy braku obiektywizmu. Można również wyraźnie powiązać okrucieństwo i agresywne zachowania dwóch mieszkańców wsi z ich doświadczeniem pobytu $\mathrm{w}$ armii, a więc kontaktem ze światem zewnętrznym, z cywilizacją dużej aglomeracji i innej niż wiejska wspólnoty. Obcym w Kujtieżach jest również kochanek Alewtiny Łomowej - Ormianin Wazgen, który porzucając kobietę w ciąży, przysporzy jej sporo cierpienia. Stosunek lokalnej społeczności do Wazgena, pełen uprzedzeń i stereotypów, jest świadectwem tendencji mieszkańców do zamykania się przed innością:

У Алевтины бурно развивался роман с кавказцем, торговавшим на рынке в райцентре. Кавказец был чужим, а чужих не любили. Тем более теперь, когда третий день неотлучно у ее дома стояла серебристо-серая иномарка, каких в Куйтежах доселе еще не видели [Мамаева 2005].

Odróżniał się od większości mieszkańców też, jak pamiętamy, Gienka: „Деревенские вроде и не любили его, и буржуем кликали, а печь у кого развалится, или что вывезти надо с Юккогубы - шли к нему. К кому еще идти-то - все остальные мужики пили, а Генка ничего, помогал. Свой ведь он все-таки, куйтежский" [Мамаева 2005]. Z kolei w opowiadaniu Butla u głównego bohatera - Koljana - absolwenta wydziału ekonomicznego i burmistrza rejonu wielikoniwskiego, właściciela czarnego BMW X5, drogiej biżuterii i luksusowych ubrań, poczucie więzi z innymi, harmonii i spokoju rodzi się dopiero we wspólnocie z mieszkańcami Putiejnego. Co prawda odczucia, które pojawiły się u mężczyzny, poprzedziło wspólne spożycie dużej ilości alkoholu, więź zaś to efekt poszukiwania przez wszystkich mieszkańców wsi zakopanej niegdyś butli samogonu, dlatego też terapeutyczna rola kolektywnego trudu ma tu raczej podtekst ironiczny.

Idealizacja patriarchalnej wsi w utworach autorki Entre nous odbywa się w dużej mierze za pomocą stworzonej koncepcji bohaterek, perspektywa oglądu świata dokonywana jest najczęściej za pośrednictwem kobiet. 
Pisarka, podobnie jak Swietłana Wasilenko w Głuptasce, „buduje świat, w którym niemal wszystko, co dobre, kojarzy się z pierwiastkiem żeńskim" [Fast 2010: 84].

Już w debiutanckiej opowieści Wesele Lenki mamy do czynienia z bohaterką, nad którą „как-то так получалось... всегда, сколько Ленка себя помнила, смеялись" [Мамаева 2005]. Szesnastolatce wydaje się, że wiedzie szczęśliwie życie dopóki nie zakochuje się w Jurce. Uczucie to jest bodźcem do nowych doznań i refleksji; sprawia, że Lena zaczyna dostrzegać kobiecą stronę swojej natury, ale też próbuje uporządkować emocje, zastanawia się nad sensem życia w kontekście miłości. Bohaterka, prosta dziewczyna, czerpiąca dotychczas radość z pracy na rzecz innych (wolała pracować w sowchozie niż w gospodarstwie rodziców) dochodzi do wniosku, że kochać drugiego człowieka to uczynić dla niego coś dobrego. Miłość jest w jej pojęciu związana z minimalizowaniem własnych potrzeb na rzecz potrzeb drugiego człowieka. W przypadku Lenki takim wyrazem miłości jest obrona ukochanego przed szarżującym na niego bykiem. Protagonistka, odwracając uwagę rozjuszonego zwierzęcia, przyjmuje na siebie atak. Otwarte zakończenie utworu nie wskazuje jednoznacznie, czy ofiara bohaterki pozwoliła jej spełnić największe marzenie, sugerowane tytułem, czy też wizja ślubu z Jurką to bredzenie poranionej przez zwierzę dziewczyny. Czyn Lenki i poprzedzająca go pokora, wyrozumiałość i miłość, cechujące bohaterkę, co znajduje odzwierciedlenie w słowach jej przyjaciółki „тебе бы только всех бы любить да жалеть!" [Мамаева 2005] są niewątpliwym wyrazem ideału bohaterów Mamajewej.

Karelska pisarska ma umiejętność tworzenia postaci przyciągających uwagę czytelnika, nietuzinkowych, wyróżniających się, czy to siłą swojej osobowości, czy też wyjątkowymi zdolnościami, a nawet dziwactwami. Z reguły są to osoby starsze. Nieprzypadkowo zapewne stają się one wyrazicielkami poglądów autorki.

W społeczności tradycyjnej niektórzy jej przedstawiciele, tacy jak dzieci, starcy i szaleńcy, posiadają odrębny od innych status. Jak pisze Jelena Olesina, są to osoby

[...] nieuczestniczące (lub mało uczestniczące) w aktywnym życiu codziennym członków społeczności, ludzie z innego świata, z przestrzeni mistycznej, ludzie, żyjący w czasie mitologicznym, czyli jakby w bezczasie. [...] Dzieci, szaleńców, starców cechuje szczególna mądrość, manifestująca się prostotą i naiwnością, będących efektem związków ze światem mistycznym, irracjonalnym, posiadania wiedzy sakralnej [Olesina 2016: 26].

Osobą reprezentująca mistyczny związek ze światem, przyrodą i Bogiem jest 70-letnia Kuźminiczna - bohaterka Ziemi Gaj. Jako jedyna z osób 
zamieszkujących wioskę nie może funkcjonować samodzielnie, opiekuje się nią starsza o dziesięć lat, ale będąca w lepszej kondycji fizycznej Michajłowna. Kuźminiczna cierpi na sklerozę, która sprawia, że jej zachowanie przypomina niekiedy zachowanie bezradnego dziecka lub szaleńca. Inność Kuźminicznej zostaje podkreślona np. strojem. Choć zarówno ona, jak i jej opiekunka zwykle noszą odzież z darów pochodzących z Finlandii, bohaterka potrafi wyróżnić się nazbyt przesadnym i kolorowym ubiorem, co w połączeniu z nieskładną i pozbawioną logiki mową (nie potrafi przypomnieć sobie słów) czyni ją w oczach postronnych dziwaczką. Kuźminiczna pochodzi z Ukrainy, przed wielu laty przyjechała do Ziemi Gaj w poszukiwaniu pracy i męża, przez lata mieszkała z synem, który jednak, w obliczu braku pracy, wyjechał z rodziną na Kubań, zapominając o starej matce. Kuźminiczna w przeszłości była partyjną aktywistką, występowała z propagandowymi odczytami, jednak obecnie jej życie jest silnie związane $\mathrm{z}$ wiarą w Boga, rozumianą w duchu panteistycznym. Kuźminiczna jest nosicielką archetypowego obrazu staruszki pojawiającej się w przełomowym momencie życia innego bohatera. W tym przypadku jest to Jegor, młody mieszkaniec wsi, rozczarowany miastem, w którym pracodawca domagał się od niego łapówek za przemilczenie faktu braku zameldowania, szukający celu w życiu, wartości, na których mógłby oprzeć własne istnienie. Staruszka zwraca jego myśli ku Bogu i afirmacji życia, manifestującego się w przyrodzie i sile tkwiącej w ziemi. Refleksja wywołana nauką Kuźminicznej sprawia, że chłopak przyjmuje chrzest, jednak spodziewając się po nim natychmiastowej odmiany losu, która oczywiście nie następuje, Jegor popada w jeszcze większą frustrację i złość, będące efektem braku miłości w jego życiu (rodzice to alkoholicy, nieokazujący uczuć i nieinteresujący się synem).

Postawie Kuźminicznej bliska jest babcia głównej bohaterki opowieści Wesele Lenki - osoba skromna, dobra, wyrozumiała, troszcząca się o bliskich, życzliwa dla otoczenia, a przy tym niepozbawiona godności osobistej i jednoznacznych zasad moralnych, będąca opoką nie tylko dla przeżywającej silne emocje Lenki, ale i innych przedstawicieli rodziny i mieszkańców wsi. Jelena Popowa to poniekąd strażniczka harmonii i ładu w lokalnej społeczności, jest nosicielką pamięci o zmarłych i rytuałów związanych ze śmiercią, jest pracowita, a to, co się jej przydarza przyjmuje ze spokojem i pokorą. Reprezentuje archetyp staruszki stojącej na straży wartości duchowych, tradycji i dziedzictwa lokalnej społeczności.

Odmienny typ reprezentuje Michajłowna z Ziemi Gaj. To zdeklarowana komunistka, odwołująca się często do idei Lenina, którego portret wisi, niczym ikona, w centralnym miejscu domu. Bohaterka przyjechała do wsi ze swoimi rodzicami wiele lat temu, gdy praktycznie trzeba było samemu organizować sobie życie na porośniętej lasem dalekiej północy. Jej biografia od- 
zwierciedla los wielu Rosjan, którzy pozytywnie odpowiedzieli na komunistyczne hasła budowy nowej ojczyzny:

\begin{abstract}
Я, все мы тута организовывали наш леспромхоз на пустом месте, в лесу - спали в сене, под открытым небом. Проработали всю войну, без выходных и праздников - правильно я говорю? - Народ одобрительно загудел. - Восстанавливали его после войны! Помните, бабоньки, как бревна вручную в вагоны грузили? - Бабки в зале одобрительно закивали: такое забудешь! - Восстанавливали его после ликвидации! Работали без выходных и праздников, ради страны, ради партии - вот энтими руками, - Михайловна показала руки. - Потому что родина требовала. За дело Ленина, Сталина! Я коммунистка с сорок восьмого года! И не стыжусь этого. И после победы вашего, - она ткнула пальцем в сторону официальных лиц, - капитализьма восстанавливали лесхоз, в начале девяностых годков - работали как до войны, без денег, за палочки - правильно я говорю?" [Мамаева 2006].
\end{abstract}

Protagonistka jest nosicielem etosu pracy komunistycznej - oddania państwu i ideologii, które zawsze były - i dla Michajłowny nadal są - na pierwszym miejscu. Dzięki swojej pracowitości i zaangażowaniu oraz wieloletniemu „zasiedzeniu” zyskała sobie wśród społeczności duży autorytet, dlatego też to ona najczęściej zabiera głos na zebraniach z przedstawicielami administracji. Jak twierdzi Andriej Szipiłow,

w patriarchalnym (archaicznym) społeczeństwie stary - to starszy, to jest człowiek, który z powodu swojej porównywalnej przewagi wiekowej prawie automatycznie występuje jako nosiciel władzy/autorytetu (auctoritas). Grec. gerōn - to członek gerusii, łac. senex - to członek senatu: starość etymologicznie związana jest nie z niedołęstwem i upadkiem, ale z władzą i wyższością. Rosyjskie "stary” lub starosłowiańskie „старцць ma indoeuropejskie korzenie o znaczeniu „duży”, „krzepki”, ,twardy”, "silny": chodzi tu bynajmniej nie o niemoc, a wręcz przeciwnie - siłę, potęgę, panowanie [Шипилов 2012].

Wszystkie cechy tworzące pole semantyczne starości utożsamianej z autorytetem i mądrością odnaleźć można u Michajłowny. Bohaterka to typ aktywny, od rana do wieczora zajęta organizowaniem bytu sobie i Kuźminicznie, przedsiębiorcza (sprzedaje mleko), ma skłonności do dydaktyzmu, biorącego się z jej komunistycznego wychowania - przestrzega i poucza sąsiadów nadużywających alkoholu, jest uczciwa i wymaga tego od innych, nie może zaakceptować rozpadu więzi międzyludzkich, do jakiego doszło po transformacji ustrojowej oraz wszechobecnego złodziejstwa. Degradacja przestrzeni, progres odbywający się za cenę zubożenia człowieka, akceptacja dla agresji i eksploatowania zasobów naturalnych wsi, napawają bohaterkę smutkiem i wywołują niepokój o przyszłość kraju i własnej wioski. Michajłowna przypomina postacie kobiet $\mathrm{z}$ utworów Walentina Rasputina - kobiet świado- 
mych dokonującego się procesu zaniku odwiecznych wartości, tradycji, wiary i relacji międzyludzkich, a więc wszystkiego tego, co świadczy o bogactwie wewnętrznym człowieka. Inną aktywną i działającą bohaterką prozy Iriny Mamajewej będzie Galina Pietrowna Rosomachina, tytułowa postać opowiadania Rosomacha, kobieta 65-letnia, której biografia odzwierciedla los wielu rosyjskich kobiet ze wsi, skazanych na ciężką pracę i brak zainteresowania ze strony bliskich. Bohaterka organizuje wokół siebie grupę ludzi wyrzuconych przez los na margines, którym daje dom i wyżywienie w zamian za pracę na roli. Po śmierci ukochanego to właśnie ci ludzie stają się dla Rosomachi rodziną, o którą troszczy się i walczy z uporem, gdy dają o sobie znać ich wcześniejsze nawyki i nałogi.

Irena Mamajewa pokazuje świat rosyjskiej wsi na progu katastrofy, której bliskie, namacalne niemal, nadejście, odczuwają mieszkańcy. Rozpad starego porządku i stylu życia, destrukcja bytu mają swoje źródła w historii i bieżącej sytuacji gospodarczo-politycznej kraju, powodując degradację moralną jednostki. Tym samym oblicze współczesnej rosyjskiej wsi staje się wyzwaniem cywilizacyjnym i zadaniem etycznym dla innych, Mamajewa bowiem swoją prozą zwraca uwagę na ginącą warstwę narodu rosyjskiego.

\section{Bibliografia}

Игрунова Н. 2007. „Я хочу рассказать вам...”. Книги 2006 года: иичный выбор. „Дружба народов", nr 1, źródło elektroniczne: http://magazines.russ.ru/druzhba/2007/1/ ia14.html (dostęp 7.09.2017).

Мамаева И. 2005. Ленкина свадъба, „Дружба народов”, nr 6, źródło elektroniczne: http:/ / magazines.russ.ru/druzhba/2005/6/ma7.html (dostęp 11.09.2017).

Мамаева И. 2006. Земля Гай, „Дружба народов”, nr 11, źródło elektroniczne: http:/ / ma gazines.russ.ru/druzhba/2006/1/ma4-pr.html (dostęp 9.09.2017).

Мамаева И. 2010. Бутыль, „Дружба народов”, nr 9, źródło elektroniczne: http://maga zines.russ.ru/druzhba/2010/9/ma4.html (dostęp 12.09.2017).

Мерзлов А. 2016. С момента перестройки в России по разным оценкам полностью исчезли oт 20 до 30 тысяч сельских населенных пунктов, źródło elektroniczne: https:/ / otr-online.ru/programmi/segodnya-v-rossii-27580/vimirayuschie-derevni-cherez-63181. html (dostęp 7.09.2017).

Микоян А. 2016. Есть ли 6 современной России деревенская проза?, źródło elektroniczne: http:/ / mediastancia.com/articles/4165/ (dostęp 7.09.2017).

Прилепин 3. Ирина Мамаева. Настоящий писатель по определению наивен, źródło elektroniczne: http://zaharprilepin.ru/ru/litprocess/intervju-o-literature/irina-ma maeva-nastoyaschii-pisatel-po-opredeleniju-naiven.html (dostęp 7.09.2017).

Шипилов А. 2012. „Старость” в прошлом и настоящем, „Аналитика культурологии”, nr 1, źródło elektroniczne: https://cyberleninka.ru/article/n/starost-v-proshlom-i-nastoyaschem (dostęp 11.09.2017). 
Conquest R. 2002. Uwagi o spustoszonym stuleciu, Poznań: Wydawnictwo Zysk i S-ka.

Eberhardt P. 2013. Sytuacja demograficzna Federacji Rosyjskiej na przełomie XX i XXI wieku, [w:] A. Mironowicz (red.), Wprowadzenie do studiów wschodnioeuropejskich, t. 3: Rosja, Lublin: Uniwersytet Marii Curie-Skłodowskiej, s. 57-86.

Fast P. 2010. Rozumem Rosji nie ogarniesz..., Mikołów: Instytut Mikołowski.

Nie mordujmy się. Z Andrzejem Lederem, filozofem kultury i psychoterapeuta rozmawia Grzegorz Sroczyński. 2015. „Duży Format”, 7.05.2015.

Olesna J. 2016. Фольклорный образ старости как культурный код, „Slavica Wratislaviensia”, nr CLXIII, Wrocław: Wydawnictwo Uniwersytetu Wrocławskiego. 